\title{
Green entrepreneurship and SME performance: the moderating effect of firm age
}

\author{
Chenli Yin ${ }^{1} \cdot$ Maria Paz Salmador ${ }^{1} \cdot$ Dan $_{\mathrm{Li}^{2}} \cdot$ M. Begoña Lloria ${ }^{3}$
}

Accepted: 13 May 2021 / Published online: 1 December 2021

(c) The Author(s) 2021

\begin{abstract}
Green entrepreneurship has been increasing with growing attention to environment protection by a variety of stakeholders. Green innovation, as the essence of green entrepreneurship, has attracted a broad range of scholarly attention with yet inconclusive findings regarding its effect on firm performance. According to our analyses of 1667 firms listed on SME board and GEM in China during the period from 2010 to 2019, we find interesting results regarding the type of green innovation involved and the moderating effect of firm age on the link between green innovation and SME performance. More precisely, we find green utility-model innovation positively influences firm performance for SMEs, whereas green invention innovation does not contribute to firm performance overall. More interesting, our empirical results suggest that older firms benefit more from both green invention innovation and green utility-model innovation than younger firms. This research contributes to the literature on green entrepreneurship as well as green innovation.
\end{abstract}

Keywords Green entrepreneurship · Green innovation · Green invention innovation · Green utility-model innovation $\cdot \mathrm{SME} \cdot$ Firm performance

\footnotetext{
M. Begoña Lloria

maria.b.lloria@uv.es

Chenli Yin

chenli.yin@estudiante.uam.es

Maria Paz Salmador

maripaz.salmador@uam.es
}

Dan Li

lid@indiana.edu

1 Department of Business Organization, Universidad Autónoma de Madrid (UAM), Ciudad Universitaria de Cantoblanco, 28049 Madrid, Spain

2 Department of Management and Entrepreneurship, Kelley School of Business, Indiana University, Bloomington, IN 47405, USA

3 Department of Business Organization, Universitat de València, Valencia, Spain 


\section{Introduction}

With the growing attention paid to global environmental protection, firms are facing pressure to take responsibility in protecting the environment in order to meet regulations from local government (Ebrahimi \& Mirbargkar, 2017) and to meet expectations from stakeholders and marketplaces (Bossle et al., 2016). In other words, firms are facing the challenge of cultivating green capability to cope with increasing pressure from the government and the public (Ambec \& Lanoie, 2008; Dangelico \& Pujari, 2010; Lee \& Min, 2015; Tang et al., 2018). Many corporate entrepreneurs have adopted environment-related strategies, such as creating a firm green image, pollution reduction, green innovation, and so forth. Green entrepreneurship has been receiving growing attention from the public and researchers. Green entrepreneurship (or environmental entrepreneurship, ecoentrepreneurship, sustainable entrepreneurship) refers to the implementation of innovations related to environmental protection (Ebrahimi \& Mirbargkar, 2017; Hockerts \& Wüstenhagen, 2010; Lober, 1998). Following Gao et al. (2019), we consider green entrepreneurship as "entrepreneurial behavior in an enterprise's green innovation of products, services, and market development to generate profit while considering environmental protection (p. 1137)".

Innovation is the core of entrepreneurship (Zacarías et al., 2015); green innovation is the essence of green entrepreneurship. Green innovation is a long-term oriented green strategy aiming to decrease the pollution of business activities on the environment by use of innovation in products, and process among others (Guo et al., 2020). To put it differently, green innovation is the betterment of a product or a process that is eco-friendly to our environment (Ebrahimi \& Mirbargkar, 2017). However, green innovation has been viewed as a controversial green strategy since some researchers argue that green innovation requires high financial investment and can be harmful to performance (Driessen et al., 2013; Palmer et al., 1995; Stucki, 2019) due to the fact that innovation requires high cost of investment, while others argue that green innovation is a green strategy that can contribute to firm growth in a long-term since green innovation bring firms sustainable competitive advantages (Dangelico \& Pujari, 2010; Porter \& Van der Linde, 1995) and new markets (Arundel \& Kemp, 2009).

To date, the literature on green entrepreneurship is emerging, yet still quite thin. The extant studies have investigated the effect of green innovation on performance with inconclusive findings. Two research gaps are likely contributing to the inconclusiveness in prior literature. First, due to the availability of data on green innovation, many scholars have examined this relationship relying on survey data (Amores-Salvadó et al., 2014; Chen et al., 2006; Chiou et al., 2011; Christmann, 2000; Doran \& Ryan, 2012; Geng et al., 2020; Lin et al., 2013; Tang et al., 2018; Weng et al., 2015). That is to say, measurements of variables are various. For instance, prior studies relying on survey data have adopted different kinds of green innovation. Items can be answered by use of the Linkert scale or by asking specific questions with regard to inputs (e.g. investment, etc.)/outcomes (e.g. products, etc.) related to green innovation. Various measurements of green 
innovation may lead to ambiguous findings. Second, when it comes to environmental strategy, extant literature has placed stress on large established firms with limited attention to other types of firms. SMEs have received limited attention (Aragón-Correa et al., 2008; Geng et al., 2020); it is the same for younger firms (Sáez-Martínez et al., 2016). Yet, considering the relatively more constrained resource basis of SMEs and younger firms than that of their large established counterparts, the burden of green innovation identified in prior research is likely to be more severe for them.

Drawing insights from the resource-based view, we first ask whether SME green entrepreneurship proxied by green innovation contributes to performance. We adopt green patents as a measurement of green innovation rather than Likert scaled measurements. Patents are generally considered as an explicit indication of innovation output and they can reflect the level of innovative activity of firms (Arundel \& Kemp, 2009). We further investigate whether firm age exerts a significant effect on the association between green entrepreneurship and SME performance, which has been overlooked in prior studies. Our analyses are based on 1667 firms listed on the SME board and GEM in China during the period from 2010 to 2019.

Our research offers several valuable contributions to the budding literature of green entrepreneurship. This study expands green entrepreneurship literature to include SMEs which have been much understudied previously. In China, SMEs account for $99 \%$ of enterprises and contribute more than half of the innovations in terms of invention, technology, and new products (Chinabgao, 2017), which highlights the essential role of SMEs in facilitating developing and implementing green innovations. Moreover, our research enriches our understanding in respect of the impact of green entrepreneurship on performance by examining varying impacts of two types of green innovations on SME performance. The detection of evidence that green innovation does not benefit younger and older firms universally, reveals the complex nature of green entrepreneurship as well its impacts on firms. By theoretically and empirically demonstrating these effects, our research provides a much more nuanced understanding of the association between green entrepreneurship and performance, therefore advancing the green entrepreneurship literature.

\section{Theoretical background \& hypotheses development}

\section{Green entrepreneurship and firm performance}

There have been different terms used to describe and capture green entrepreneurship, such as environmental entrepreneurship (Dean \& McMullen, 2007; Hendrickson \& Tuttle, 1997; Keogh \& Polonsky, 1998; Lober, 1998), sustainable entrepreneurship (Hockerts \& Wüstenhagen, 2010; Muñoz, 2013; Schaltegger \& Wagner, 2011), eco-entrepreneurship (or ecopreneurship; Holt, 2011; Isaak, 2005; Pastakia, 1998; Schaltegger, 2016). One common aspect of these terms is 
to decrease the negative impacts of business activities on the environment and meanwhile earn profits. In this study, we follow Gao et al. (2019) and define green entrepreneurship as entrepreneurial behavior in organizational innovation of products or processes among others to gain profit while concerning environmental protection. Green innovation, as one of the green entrepreneurial activities, has been considered as an effective strategy to protect the environment and generate profit (Lee \& Min, 2015).

Green innovation can allow firms to pursue environmental performance and financial performance simultaneously (Dangelico \& Pujari, 2010; Lee \& Min, 2015; Li, 2014; Triguero et al., 2013); yet, empirical findings are inconclusive (AguileraCaracuel \& Ortiz-de-Mandojana, 2013; Chen et al., 2006; Chiou et al., 2011; Eiadat et al., 2008; Geng et al., 2020; Klassen \& McLaughlin, 1996; Lin et al., 2013; Melnyk et al., 2003; Weng et al., 2015). For instance, Doran and Ryan (2012) conclude that green innovation improves firm performance using Irish Community Innovation Survey data 2006-2008. In line with Doran and Ryan's (2012) finding, Zhang et al. (2019) also discover that green innovation contributes to performance based on manufacturing firms listed on the mainboard in China. Stucki (2019) found that investment in green energy technology exerts a positive impact on productivity only if a firm has very high energy costs based on survey data. Driessen et al. (2013) address that green innovation lowers financial performance based on analysis of case study.

Green innovation, as the essence of green entrepreneurship, often demands a high cost of investment, which increases a firm's financial burden (Ambec \& Lanoie, 2008; Arundel \& Kemp, 2009; Cai \& Li, 2018; Palmer et al., 1995; Woo et al., 2014; Zhang et al., 2019). Meanwhile, there are many barriers for green innovation to succeed including technological barriers (e.g. availability of technology), labor force-related barriers (e.g. lack of staffs in management of technology), and so forth (Arundel \& Kemp, 2009; Gossart \& Ozaygen, 2016; Hillary, 2004; Hrabynskyi et al., 2017; Kaenzig \& Wüstenhagen, 2010; Marin et al., 2015; Murillo-Luna et al., 2011; Ockwell et al., 2010; Polzin et al., 2016). The financial burden and barriers stress the difficulty of green entrepreneurial activities for all firms. It is particularly challenging for SMEs characterized by limited resources and capabilities, which can constrain their implementation of the environmental strategy (Hillary, 2004; Nunes et al., 2019).

Despite the challenges, we argue that, overall, green innovation positively influences SME firm performance. Green innovation can bring an SME economic performance not only by use of physical resources and technology but also intangible resources. On the one hand, green innovation contributes to economic performance by lowering cost, increasing productivity, or differentiating products that can gain market position (Ambec \& Lanoie, 2008; Aragón-Correa \& Sharma, 2003; Hart, 1995; Ma et al., 2018; Weng et al., 2015). A firm can achieve economic performance by recognizing the insufficient physical resources possessed by itself, and converting the insufficient resources into an advantage (Russo \& Fouts, 1997) by use of technology. For instance, firms can redesign product or production processes to improve resource efficiency and reduce cost 
(e.g. materials, etc.), leading to improve productivity (Berry \& Rondinelli, 1998; Florida, 1996; Ma et al., 2018). Besides, firms can also improve economic performance by use of materials that can be recycled (Burgos-Jiménez et al., 2013; Ma et al., 2018) as recycled resources are less expensive.

On the other hand, green innovation can shape firms' green image, and improve firms' reputation (Ambec \& Lanoie, 2008; Amores-Salvadó et al., 2014; AragónCorrea \& Sharma, 2003; Dangelico \& Pujari, 2010; Eiadat et al., 2008; Triguero et al., 2013). The resource-based view suggests that firms achieve competitive advantages relying on not only tangible resources or technology but also intangible resources (Barney, 1991; Russo \& Fouts, 1997). Green innovation can shape a firm's green image. Stakeholders, for example, consumers, review firms with green images more positively (Amores-Salvadó et al., 2014; Dangelico \& Pujari, 2010; Sambasivan et al., 2013). Marketing researchers have concluded that firms' environmental commitment can be an attractive strategy to attract consumers who have a good sense of environment protection, further increasing profit (Nair \& Menon, 2008; Ottman et al., 2006). Green innovation increases firm environment-friendly image (Amores-Salvadó et al., 2014; Chen et al., 2006; Fraj-Andrés et al., 2009), which increases consumers' perception of environmental commitment and enhance consumers' loyalty (Russo \& Fouts, 1997), leading to financial benefits. In this study, green innovation refers to both green invention innovation (also known as conventional/standard innovation) and green utility-model innovation. More precisely, green invention innovation refers to original innovation, while green utility-model innovation refers to applied technologies that reform a product's structure (Suthersanen, 2006). An invention patent is most valuable to firms (Sun et al., 2008), while a utility-model patent has lower application requirements (Prud'homme, 2017), and shorter application duration, and lower cost (Suthersanen, 2006), which is also advantageous for SMEs. We, therefore, argue that both types of green innovation (green invention innovation and green utility-model innovation) will contribute to SME performance and offer our baseline hypotheses.

Hypothesis 1a: Green invention innovation positively influences SME performance. Hypothesis 1b: Green utility-model innovation positively influences SME performance.

\section{Green entrepreneurship, age and firm performance}

We further argue that firm age exerts a significant impact on the link between green entrepreneurship and SME performance. Extant studies have discovered that firm age influences a firm's innovation activities, yet the results are not consistent. Some researchers argue that firm age negatively influences innovation (Hansen, 1992; Huergo \& Jaumandreu, 2004; Lee \& Sung, 2005; Shefer \& Frenkel, 2005), whereas others argue that firm age positively influences innovation (Sørensen \& Stuart, 2000; Withers et al., 2011). There are also researchers who conclude that the association between firm age and innovation activity is inverted U-shape (Fan \& Wang, 2019) 
and that no significant association between them at all (Avermaete et al., 2003; Baregheh et al., 2016).

Indeed, older firms often have well-established external relationships that can bring access to resources necessary to produce innovation (Withers et al., 2011). Prior related experience and knowledge are also essential to a firm's innovation (Cohen \& Levinthal, 1990; Sørensen \& Stuart, 2000). That is, accumulated experience and knowledge from prior experiments, both successes, and failures can lead to innovation achievements in the future (Miyazaki, 1994; Withers et al., 2011). Therefore, comparing with younger firms, it is more likely that older firms have more green entrepreneurial activities due to experiences and knowledge that are essential to produce green innovation. Besides, older firms have more developed routines concerning entrepreneurial strategies or business activities (Withers et al., 2011), which play a critical role in facilitating green entrepreneurial activities; whereas younger firms often lack knowledge in terms of business activities, or organizational norm among others (Anderson \& Eshima, 2013; Kilenthong et al., 2016). Thus, we hypothesize that resources possessed by older firms (such as external relationships, accumulation of knowledge from the past, etc.) lead to more green innovation activity, eventually leading to an increase in firm performance. We propose our second set of hypotheses:

Hypothesis 2a: Comparing to younger firms, the positive effect of green invention innovation on SME performance is stronger for older firms.

Hypothesis 2b: Comparing to younger firms, the positive effect of green utility-model innovation on SME performance is stronger for older firms

\section{Methods}

\section{Sample}

We retrieve our sample firms from the Small and Medium-sized Enterprise (SME) board and Growth Enterprise Market (GEM). The SME board and GEM were established in 2004 and 2009 in the Shenzhen Stock Exchange in China; both concentrate on funding SMEs (Zhen, 2013). Firms listed on the SME board and GEM are characterized by SMEs.

We collect data from several data sources. We first obtain patent information from China National Intellectual Property Administration (CNIPA). Next, we identify green patents according to the International Patent Classification (IPC) of green inventory list offered by the World Intellectual Property Organization (WIPO). Finally, we collect the rest of the data from the China Stock Market \& Accounting Research Database, a research-oriented database focusing on finance and the economy. After combining all data, our final sample has 1667 SMEs from 2010 to 2019. 


\section{Variables and model}

Dependent variable Following Jiang et al. (2010), we measure a firm's performance using net profit margin, denoted as variable Net profit margin. As an accounting measurement, the net profit margin reflects a firm's profitability.

Independent and moderating variables We use a firm's green patents to capture its green entrepreneurship (Arundel \& Kemp, 2009; Oltra et al., 2010) and count the firm's green patents based on the application year. It takes time for the impact of innovation to materialize in performance (Artz et al., 2010; Lee et al., 2019); we, therefore, consider a lag effect. Thus, we apply the total number of green patents of the last three years (including the current year) to measure the green innovation of a firm, denoted as variable Green invention innovations and Green utility-model innovations, respectively. A green patent refers to a patent providing environmental benefits. A green invention patent emphasizes an original innovation, whereas a green utility-model patent emphasizes reform a product's structure.

In our sample, a firm is younger than 5 years old is less likely to have applications of green patent records. Thus, for our research purpose, we follow prior researchers (Brush \& Vanderwerf, 1992; Kilenthong et al., 2016) who consider a firm as a younger firm if its age is six years old or younger. We use the variable, Older firms, taking a value of 1 if a firm is older than six years, otherwise 0 .

Control variables With the purpose of controlling the impact of firm size on performance (Eisingerich et al., 2009), we use the logarithm of the number of employees (Bos et al., 2017; Popadic et al., 2016; Wuyts \& Dutta, 2014) denoted as variable Firm size. Since firms established early are more likely to have more access to resources or more experience in the industry, which has influences on firm performance. Established years, therefore, is controlled (Fan \& Wang 2019). Due to the fact that leverage influences a firm's economic performance, we also control Leverage (Chen et al., 2018; Hayat et al., 2020). To tease out other innovation effects, we control a firm's total number of non-green invention and non-green utility-model innovations of the past three years (including the current year).

We employ a fixed-effects model with White's correction, which solves heteroskedasticity issues. A fixed-effects model can reduce the unobservable effects caused by omitted variables. Further, we also include the year dummy in our model in order to remove year-related heterogeneity. Therefore, our model control firmand year-specific effects. 


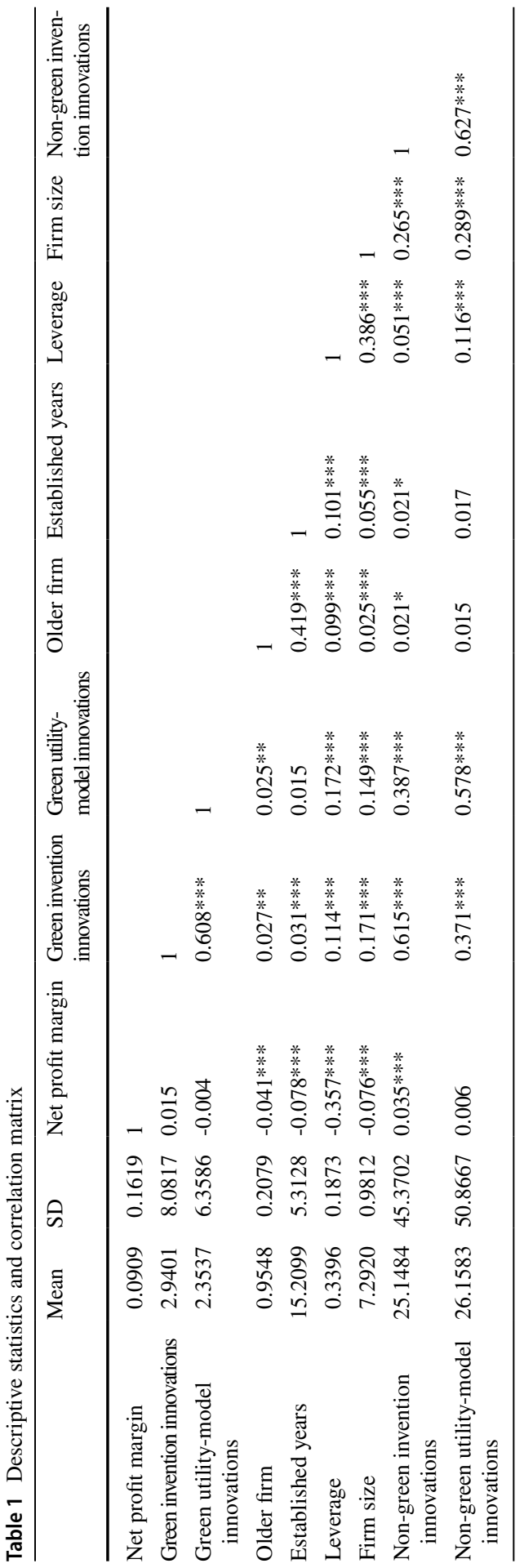




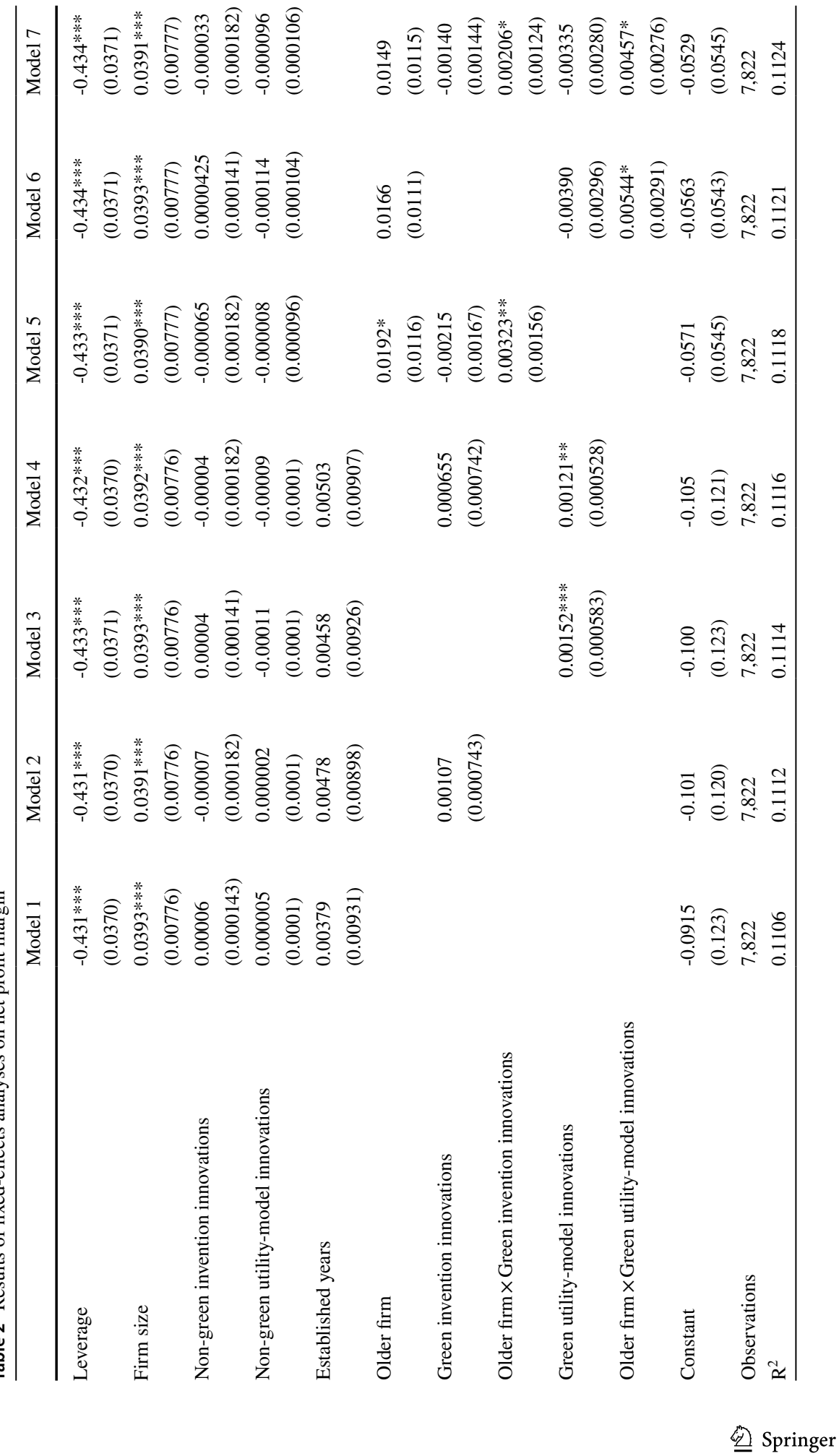




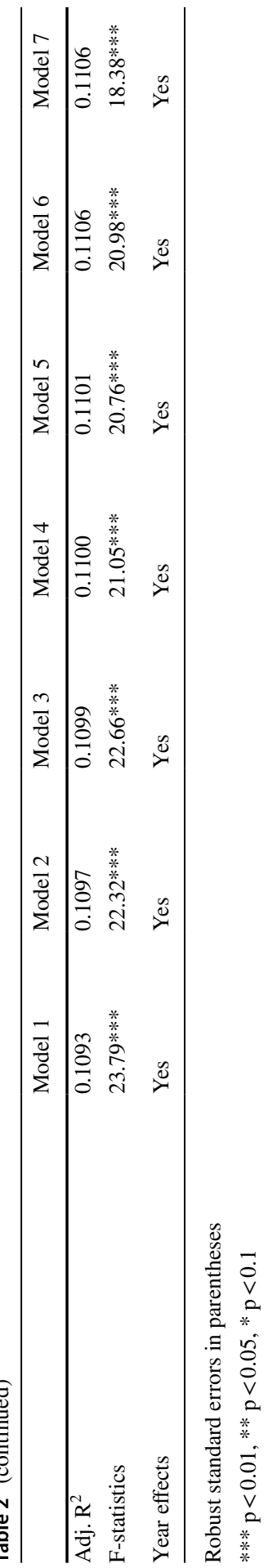

照) Springer 


\section{Results}

Descriptive statistics and correlation matrix are given in Table 1. As shown, results reveal that there is no multicollinearity issue in this study. Further, we also examine variance inflation factor (VIF), and results confirm that no collinearity issue as the mean VIF value is smaller than the critical value, 10 (Wooldridge, 2016).

Table 2 gives the results of the fixed-effects analyses. Model 1 is our base model, only with our control variables. Model 2 includes the independent variable, Green invention innovation, into the base model, predicting that Green invention innovation positively influences firm performance. Although the sign of the coefficient on Green invention innovation is positive as predicted in Hypothesis 1a, it is not statistically significant $(\beta=0.00107, \mathrm{p}>0.1)$, providing no empirical evidence for Hypothesis 1a. Model 3 tests the impact of Green utility-model innovation on firm performance. Results reveal a positive and significant effect $(\beta=0.00152, \mathrm{p}<0.01)$, providing strong evidence supporting that Green utility-model innovation positively influences firm performance. Model 4 includes both independent variables; the results are in line with those in Models 2 and 3 with the coefficient on Green invention innovation being positive but not statistically significant $(\beta=0.000655$, $\mathrm{p}>0.1$ ) and the coefficient on Green utility-model innovation being positive and statistically significant $(\beta=0.00121, \mathrm{p}<0.05)$. Therefore, Hypothesis 1a is not supported and Hypothesis $1 \mathrm{~b}$ received strong empirical support.

Model 5 includes the interaction effect of Older firm and Green invention innovation on firm performance. And results reveal that it is positive and statistically significant $(\beta=0.00323, \mathrm{p}<0.05)$. To better understand the statistically significant coefficient of the interaction term accompanied by a not-statisticallysignificant finding on the main relationship, we plot the moderating effect in Fig. 1. The $\mathrm{y}$-axis and the $\mathrm{x}$-axis represent the dependent variable (Net profit margin) and green invention innovation level, respectively. It is interesting to observe that the net profit margin increases with an increase in green invention innovation for older firms (represented by the dotted line). It is even more

Fig. 1 Interaction effect of old firm and green invention innovations on net profit margin

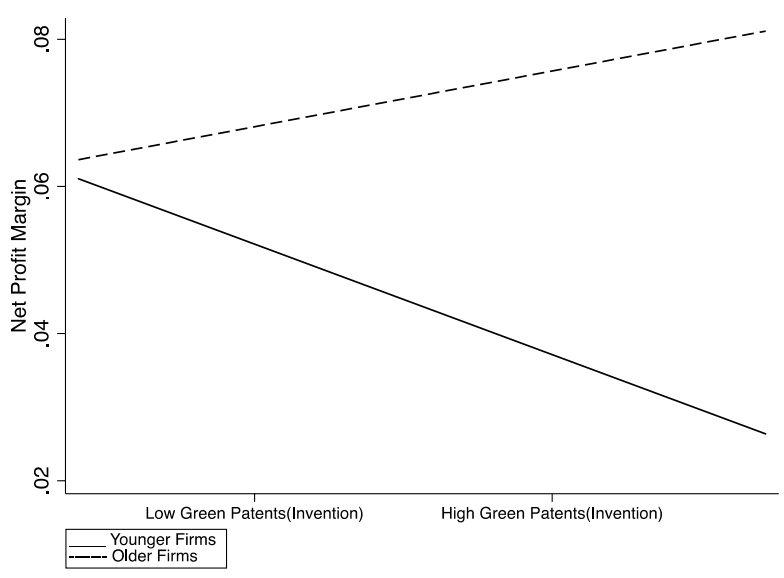


Fig. 2 Interaction effect of old firm and green utility-model innovations on net profit margin

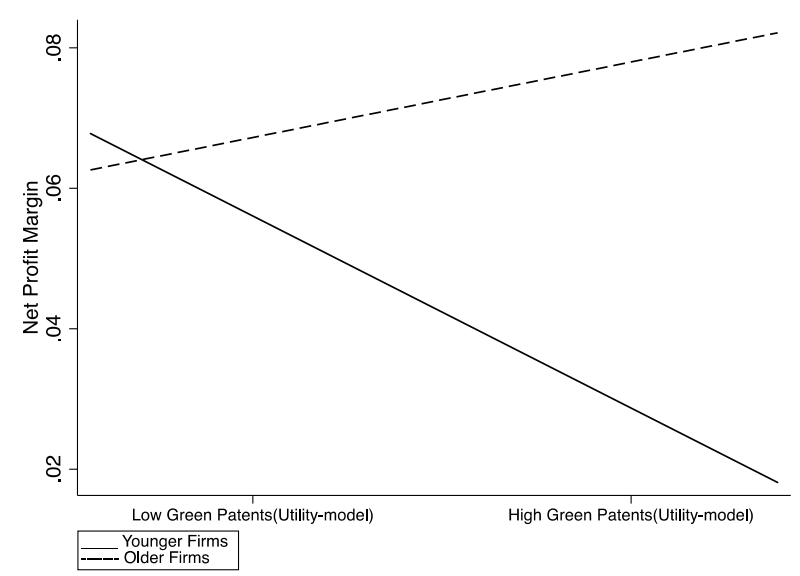

interesting that the figure shows a negative relationship between green invention innovation and net profit margin for younger firms. Hypothesis $2 \mathrm{a}$ is thus supported.

Hypothesis $\mathrm{H} 2 \mathrm{~b}$ predicts that the positive association between Green utilitymodel innovation and performance is stronger for older firms. Model 6 reveals that the coefficient of the interaction term between Older firm and Green utility-model innovation is positive and statistically significant $(\beta=0.00544, \mathrm{p}<0.1)$, providing evidence that supports Hypothesis $2 \mathrm{~b}$. Model 7 includes both independent variables and their interaction terms. The results show both interaction terms remain statistically significant $(\beta=0.00206, \mathrm{p}<0.1 ; \beta=0.00457, \mathrm{p}<0.1)$, consistent with findings in Models 5 and 6. Thus, our second set of hypotheses are supported. We also plot the interaction effect of Older firm and Green utility-model innovation on firm performance in Fig. 2. As shown, net profit margin (y-axis) increases with increases in green utility-model innovation (x-axis) for older firms (the dotted line). The figure also shows a negative association between green utility-model innovation and net profit margin for younger firms.

\section{Robustness test}

Firms listed on Growth Enterprise Market are characterized by great growth potential (Zhen, 2013). In order to examine our empirical findings not influenced by market characteristics, we test our models again after excluding firms listed on Growth Enterprise Market. And the findings are reported in Table 3 (see Appendix). Models 1 and 2 re-test Hypothesis 1a and Hypothesis 1b, predicting that Green invention innovation and Green utility-model innovation positively influence performance, respectively. And Model 3 adds both independent variables. The results reveal that the positive impact of Green invention innovation on performance is not statistically significant; and the Green utility-model 
innovation exerts a significant and positive impact on performance, which confirms empirical findings regarding $\mathrm{H} 1 \mathrm{a}$ and $\mathrm{H} 1 \mathrm{~b}$ above. Models 4 and 5 re-test the interaction effects of Older firm and Green invention innovation, Older firm, and Green utility-model innovation on performance. Results manifest that both interaction terms are statistically significant $(\beta=0.00176, p<0.1 ; \beta=0.00282$, $\mathrm{p}<0.05)$. Model 6 includes both independent variables, Green invention innovation and Green utility-model innovation, and their interaction terms. The results reveal that the interaction term of Older firm and Green invention innovation share the same positive sign with our finding of $\mathrm{H} 2 \mathrm{a}$ above, and the interaction term of Older firm and Green utility-model innovation is statistically significant, confirming our empirical findings above.

\section{Discussion and conclusions}

Our research investigates the impact of green entrepreneurship proxied by green innovation on SME performance and whether the association is different between older firms and younger firms using data of 1667 firms listed on the SME board and GEM in China during the period from 2010 to 2019. Results suggest that green utility-model innovation exerts a significant and positive impact on performance. However, we fail to find evidence supporting that green invention innovation positively influences firm performance. This may be because of the distinctions of utility-model innovation comparing with invention innovation. Utility-model innovation is characterized by lower application criteria, cheaper fees and shorter application duration, and shorter legal protection duration (Prud'homme, 2017). That is, the shorter granting process allows fast commercialization of technologies, which plays a critical role in technologies with a shorter lifecycle (Suthersanen, 2006). Our results also suggest that the effect of green invention/utility-model innovation on SME performance is stronger for older firms. It seems extremely challenging for younger SMEs to benefit from any green entrepreneurship initiative, invention, or utility based.

Our research makes several theoretical and managerial contributions. First, this research enriches green entrepreneurship literature by differentiating different types of green innovation. Our findings on the varying effects of green invention vs. green utility-model innovation enrich the current understanding in respect of the association between green entrepreneurship and performance. At least in the context of this study, green invention innovation does not contribute to SME performance. While prior research has focused on the overall green entrepreneurship, we demonstrate that the richness and complexity of firms' green entrepreneurial initiatives are important for future studies to take into consideration.

Second, our research contributes to green entrepreneurship literature by offering a comparison older and younger firms in respect of the effect of green entrepreneurship on firm performance. Our empirical findings suggest that older firms benefit from green entrepreneurial activities. However, younger firms do not benefit from either type of green innovation. It will be worthwhile for future studies to investigate 
whether age plays a role in large firms' green entrepreneurship initiatives. Considering the theoretical arguments on the accumulation of experience, knowledge, and resources over time, we speculate that age would play a similarly important role for large firms as well. Future research avenues along this theme are promising.

Lastly, we fille the research gap of the existing green entrepreneurship literature that focuses on large firms and has largely overlooked SMEs when it comes to environmental strategy. By use of firm data collected from SME board and GEM in China, this research enriches our understanding of the association between environment-friendly innovations and performance. Our findings support that green innovations give small and medium-sized firms incentive to engage in environment-related innovations.

Our study also makes managerial contributions. For instance, with increasing attention to environmental protection from the public, firms are facing the challenge to go "green". Green innovation, as the essence of green entrepreneurship, can boost economic growth. Firms may adopt different innovation strategies to cope with pressure from local government and stakeholders (e.g. customers). Given the consensus that younger firms have limited resources, policymakers of younger firms may concern other types of investment in environment-related activities, apart from green innovations. For instance, adopting energy-saving equipment. As our findings suggested, green innovations do not bring benefits for younger firms. Investment in green innovations is accompanied by uncertainty, meaning that green innovations are very risky. To put it differently, green innovations are challenges to younger firms since younger firms are lack of accumulated resources and knowledge necessary to produce green innovations. Younger firms may suffer a great loss due to failures of green R\&D experiments.

There are limitations in this study. First, we only focus on firms listed on the SME board and GEM in China, which limits the generalization of empirical findings. Environment-related regulations are variations across countries. Thus, further study with a broader empirical context is needed. In addition, we use green patents to measure a firm's green entrepreneurial activity. Green patents can capture efforts that a firm makes in protecting the environment. However, it may be not a good measurement when a firm adopts other kinds of green entrepreneurial strategies such as adopting energy-saving facilities, utilizing environmentfriendly materials, and so forth. Future studies may consider a measurement of green innovation that captures a wide variety of green innovative activity. Furthermore, we fail to find empirical evidence supporting the hypothesis that green invention innovation positively influences firm performance. Green invention innovation is characterized by higher application criteria, longer granting process, and long legal protection duration, which may be more severe for SMEs. Our results suggest that SMEs benefit from green utility-model innovation, not green invention innovation. To put it differently, SMEs benefit from green utility innovation that has a lower cost. The future study therefore may investigate the effects of characteristics of green innovation and further examine its impact on performance. Future research may also explore whether there are differences between SMEs and their large established counterparts concerning the benefit from green innovation. Large established firms are distinguished with resource advantages, thus green innovation preference and its impact on performance may vary between large firms and SMEs. 


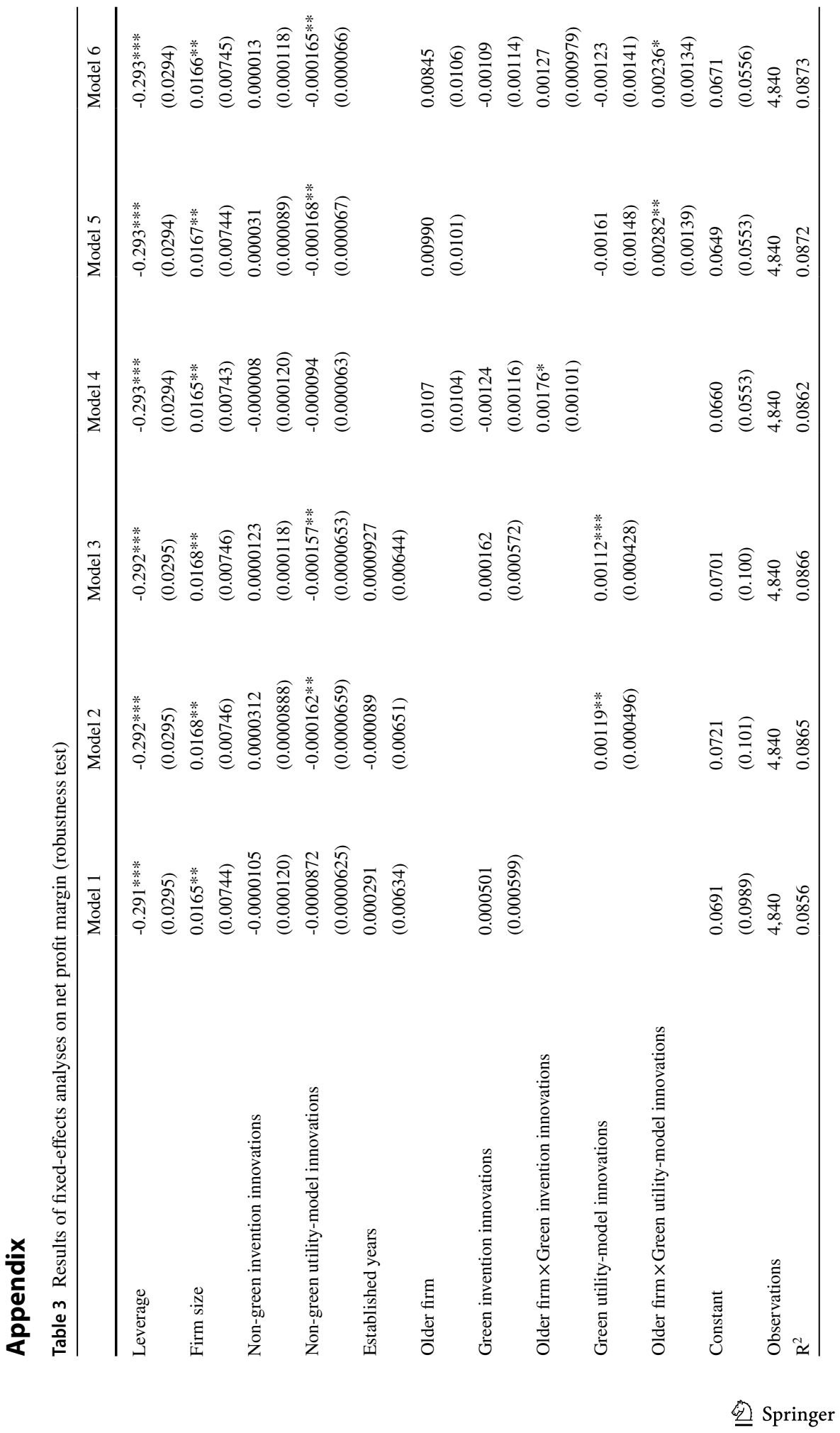




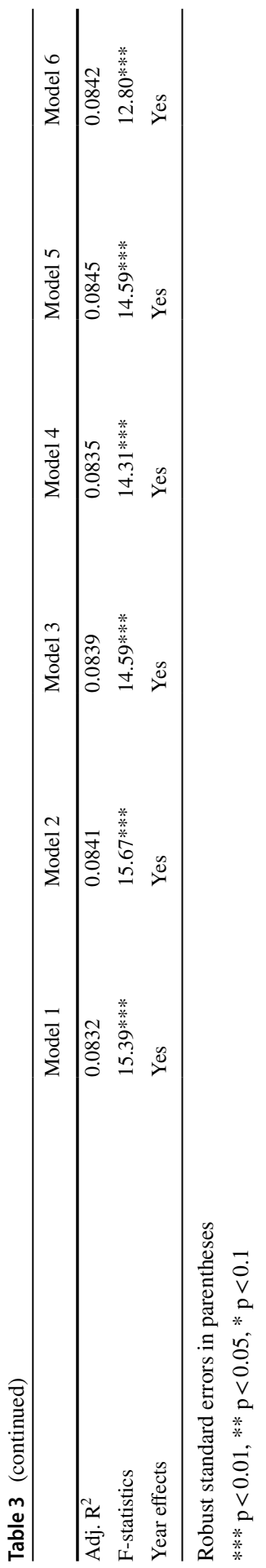

管 Springer 
Funding Open Access funding provided thanks to the CRUE-CSIC agreement with Springer Nature.

Availability of data and material The raw/processed data required to reproduce these findings cannot be shared at this time as the data also forms part of an ongoing study.

Code availability Not applicable.

\section{Declarations}

Conflicts of interest/Competing interests The authors declare that there is no conflict of interests regarding the publication of this article.

Open Access This article is licensed under a Creative Commons Attribution 4.0 International License, which permits use, sharing, adaptation, distribution and reproduction in any medium or format, as long as you give appropriate credit to the original author(s) and the source, provide a link to the Creative Commons licence, and indicate if changes were made. The images or other third party material in this article are included in the article's Creative Commons licence, unless indicated otherwise in a credit line to the material. If material is not included in the article's Creative Commons licence and your intended use is not permitted by statutory regulation or exceeds the permitted use, you will need to obtain permission directly from the copyright holder. To view a copy of this licence, visit http://creativecommons.org/ licenses/by/4.0/.

\section{References}

Aguilera-Caracuel, J., \& Ortiz-de-Mandojana, N. (2013). Green innovation and financial performance: an institutional approach. Organization \& Environment, 26(4), 365-385.

Ambec, S., \& Lanoie, P. (2008). Does it pay to be green? A systematic overview. The Academy of Management Perspectives, 45-62.

Amores-Salvadó, J., Martín-de Castro, G., \& Navas-López, J. E. (2014). Green corporate image: Moderating the connection between environmental product innovation and firm performance. Journal of Cleaner Production, 83, 356-365.

Anderson, B. S., \& Eshima, Y. (2013). The influence of firm age and intangible resources on the relationship between entrepreneurial orientation and firm growth among Japanese SMEs. Journal of Business Venturing, 28(3), 413-429.

Aragón-Correa, J. A., Hurtado-Torres, N., Sharma, S., \& García-Morales, V. J. (2008). Environmental strategy and performance in small firms: a resource-based perspective. Journal of Environmental Management, 86(1), 88-103.

Aragón-Correa, J. A., \& Sharma, S. (2003). A contingent resource-based view of proactive corporate environmental strategy. Academy of Management Review, 28(1), 71-88.

Artz, K. W., Norman, P. M., Hatfield, D. E., \& Cardinal, L. B. (2010). A longitudinal study of the impact of R\&D, patents, and product innovation on firm performance. Journal of Product Innovation Management, 27(5), 725-740.

Arundel, A., \& Kemp, R. (2009). Measuring eco-innovation.

Avermaete, T., Viaene, J., Morgan, E. J., \& Crawford, N. (2003). Determinants of innovation in small food firms. European Journal of Innovation Management.

Baregheh, A., Rowley, J., \& Hemsworth, D. (2016). The effect of organisational size and age on position and paradigm innovation. Journal of Small Business and Enterprise Development.

Barney, J. (1991). Firm resources and sustained competitive advantage. Journal of Management, 17(1), 99-120.

Berry, M. A., \& Rondinelli, D. A. (1998). Proactive corporate environmental management: a new industrial revolution. Academy of Management Perspectives, 12(2), 38-50.

Bos, B., Faems, D., \& Noseleit, F. (2017). Alliance concentration in multinational companies: Examining alliance portfolios, firm structure, and firm performance. Strategic Management Journal, 38(11), 2298-2309. 
Bossle, M. B., de Barcellos, M. D., Vieira, L. M., \& Sauvée, L. (2016). The drivers for adoption of ecoinnovation. Journal of Cleaner Production, 113, 861-872.

Brush, C. G., \& Vanderwerf, P. A. (1992). A comparison of methods and sources for obtaining estimates of new venture performance. Journal of Business Venturing, 7(2), 157-170.

Cai, W., \& Li, G. (2018). The drivers of eco-innovation and its impact on performance: Evidence from China. Journal of Cleaner Production, 176, 110-118.

Chen, J., Leung, W. S., \& Evans, K. P. (2018). Female board representation, corporate innovation and firm performance. Journal of Empirical Finance, 48, 236-254.

Chen, Y.-S., Lai, S.-B., \& Wen, C.-T. (2006). The influence of green innovation performance on corporate advantage in Taiwan. Journal of Business Ethics, 67(4), 331-339.

Chiou, T.-Y., Chan, H. K., Lettice, F., \& Chung, S. H. (2011). The influence of greening the suppliers and green innovation on environmental performance and competitive advantage in Taiwan. Transportation Research Part E: Logistics and Transportation Review, 47(6), 822-836.

Chinabgao (2017). Analysis of the number of small and medium-sized enterprises in China., Retrieved from http://m.chinabgao.com/k/qiye/28142.html, Chinabgao (2017)

Christmann, P. (2000). Effects of "best practices" of environmental management on cost advantage: the role of complementary assets. Academy of Management Journal, 43(4), 663-680.

Cohen, W. M., \& Levinthal, D. A. (1990). Absorptive capacity: a new perspective on learning and innovation. Administrative Science Quarterly, 128-152.

Dangelico, R. M., \& Pujari, D. (2010). Mainstreaming green product innovation: Why and how companies integrate environmental sustainability. Journal of Business Ethics, 95(3), 471-486.

Dean, T. J., \& McMullen, J. S. (2007). Toward a theory of sustainable entrepreneurship: Reducing environmental degradation through entrepreneurial action. Journal of Business Venturing, 22(1), 50-76.

de Burgos-Jiménez, J., Vázquez-Brust, D., Plaza-Úbeda, J. A., \& Dijkshoorn, J. (2013). Environmental protection and financial performance: an empirical analysis in Wales. International Journal of Operations \& Production Management.

Doran, J., \& Ryan, G. (2012). Regulation and firm perception, eco-innovation and firm performance. European Journal of Innovation Management.

Driessen, P. H., Hillebrand, B., Kok, R. A., \& Verhallen, T. M. (2013). Green new product development: the pivotal role of product greenness. IEEE Transactions on Engineering Management, 60(2), 315-326.

Ebrahimi, P., \& Mirbargkar, S. M. (2017). Green entrepreneurship and green innovation for SME development in market turbulence. Eurasian Business Review, 7(2), 203-228.

Eiadat, Y., Kelly, A., Roche, F., \& Eyadat, H. (2008). Green and competitive? An empirical test of the mediating role of environmental innovation strategy. Journal of World Business, 43(2), 131-145.

Eisingerich, A. B., Rubera, G., \& Seifert, M. (2009). Managing service innovation and interorganizational relationships for firm performance: To commit or diversify? Journal of Service Research, 11(4), 344-356.

Fan, S., \& Wang, C. (2019). Firm age, ultimate ownership, and R\&D investments. International Review of Economics \& Finance, 76, 1245-1246.

Florida, R. (1996). Lean and green: the move to environmentally conscious manufacturing. California Management Review, 39(1), 80-105.

Fraj-Andrés, E., Martinez-Salinas, E., \& Matute-Vallejo, J. (2009). A multidimensional approach to the influence of environmental marketing and orientation on the firm's organizational performance. Journal of Business Ethics, 88(2), 263.

Gao, Y., Tsai, S.-B., Zhang, S., \& Li, G. (2019). Green entrepreneurship in transitional economies: Breaking through the constraints of legitimacy. In Green Business: Concepts, Methodologies, Tools, and Applications (pp. 1136-1160). IGI Global.

Geng, D., Lai, K., \& Zhu, Q. (2020). Eco-innovation and its role for performance improvement among Chinese small and medium-sized manufacturing enterprises. International Journal of Production Economics, 107869.

Gossart, C., \& Ozaygen, A. (2016). Barriers to eco-innovation in the LED sector: a multilevel perspective. Available at SSRN 2875847.

Guo, Y., Wang, L., \& Chen, Y. (2020). Green entrepreneurial orientation and green innovation: the mediating effect of supply chain learning. SAGE Open, 10(1), 2158244019898798.

Hansen, J. A. (1992). Innovation, firm size, and firm age. Small Business Economics, 4(1), 37-44.

Hart, S. L. (1995). A natural-resource-based view of the firm. Academy of Management Review, 20(4), 986-1014. 
Hayat, N., Hussain, A., \& Lohano, H. D. (2020). Eco-labeling and sustainability: a case of textile industry in Pakistan. Journal of Cleaner Production, 252, 119807.

Hendrickson, L. U., \& Tuttle, D. B. (1997). Dynamic management of the environmental enterprise: a qualitative analysis. Journal of Organizational Change Management.

Hillary, R. (2004). Environmental management systems and the smaller enterprise. Journal of Cleaner Production, 12(6), 561-569.

Hockerts, K., \& Wüstenhagen, R. (2010). Greening Goliaths versus emerging Davids-Theorizing about the role of incumbents and new entrants in sustainable entrepreneurship. Journal of Business Venturing, 25(5), 481-492.

Holt, D. (2011). Where are they now? Tracking the longitudinal evolution of environmental businesses from the 1990s. Business Strategy and the Environment, 20(4), 238-250.

Hrabynskyi, I., Horin, N., \& Ukrayinets, L. (2017). Barriers and drivers to eco-innovation: Comparative analysis of Germany, Poland and Ukraine. Ekonomicko-Manazerske Spektrum, 11(1), 13-24.

Huergo, E., \& Jaumandreu, J. (2004). How does probability of innovation change with firm age? Small Business Economics, 22(3-4), 193-207.

Isaak, R. (2005). The making of the ecopreneur. Making Ecopreneurs: Developing Sustainable Entrepreneurship, 2 .

Jiang, R. J., Tao, Q. T., \& Santoro, M. D. (2010). Alliance portfolio diversity and firm performance. Strategic Management Journal, 31(10), 1136-1144.

Kaenzig, J., \& Wüstenhagen, R. (2010). The effect of life cycle cost information on consumer investment decisions regarding eco-innovation. Journal of Industrial Ecology, 14(1), 121-136.

Keogh, P. D., \& Polonsky, M. J. (1998). Environmental commitment: A basis for environmental entrepreneurship? Journal of Organizational Change Management, 11(1), 38-49.

Kilenthong, P., Hultman, C. M., \& Hills, G. E. (2016). Entrepreneurial marketing behaviours: Impact of firm age, firm size and firm's founder. Journal of Research in Marketing and Entrepreneurship.

Klassen, R. D., \& McLaughlin, C. P. (1996). The impact of environmental management on firm performance. Management Science, 42(8), 1199-1214.

Lee, C.-Y., \& Sung, T. (2005). Schumpeter's legacy: a new perspective on the relationship between firm size and R\&D. Research Policy, 34(6), 914-931.

Lee, K.-H., \& Min, B. (2015). Green R\&D for eco-innovation and its impact on carbon emissions and firm performance. Journal of Cleaner Production, 108, 534-542.

Lee, R., Lee, J.-H., \& Garrett, T. C. (2019). Synergy effects of innovation on firm performance. Journal of Business Research, 99, 507-515.

Li, Y. (2014). Environmental innovation practices and performance: Moderating effect of resource commitment. Journal of Cleaner Production, 66, 450-458.

Lin, R.-J., Tan, K.-H., \& Geng, Y. (2013). Market demand, green product innovation, and firm performance: Evidence from Vietnam motorcycle industry. Journal of Cleaner Production, 40, 101-107.

Lober, D. J. (1998). Pollution prevention as corporate entrepreneurship. Journal of Organizational Change Management.

Ma, Y., Yin, Q., Pan, Y., Cui, W., Xin, B., \& Rao, Z. (2018). Green product innovation and firm performance: Assessing the moderating effect of novelty-centered and efficiency-centered business model design. Sustainability, 10(6), 1843.

Marin, G., Marzucchi, A., \& Zoboli, R. (2015). SMEs and barriers to eco-innovation in the EU: Exploring different firm profiles. Journal of Evolutionary Economics, 25(3), 671-705.

Melnyk, S. A., Sroufe, R. P., \& Calantone, R. (2003). Assessing the impact of environmental management systems on corporate and environmental performance. Journal of Operations Management, 21(3), 329-351.

Miyazaki, K. (1994). Search, learning and accumulation of technological competences; the case of optoelectronics. Industrial and Corporate Change, 3(3), 631-654.

Muñoz, P. (2013). The distinctive importance of sustainable entrepreneurship. Current Opinion in Creativity, Innovation and Entrepreneurship, 2(1).

Murillo-Luna, J. L., Garcés-Ayerbe, C., \& Rivera-Torres, P. (2011). Barriers to the adoption of proactive environmental strategies. Journal of Cleaner Production, 19(13), 1417-1425.

Nair, S. R., \& Menon, C. G. (2008). An environmental marketing system-a proposed model based on Indian experience. Business Strategy and the Environment, 17(8), 467-479.

Nunes, J. R. R., da Silva, J. E. A. R., da Silva Moris, V. A., \& Giannetti, B. F. (2019). Cleaner production in small companies: Proposal of a management methodology. Journal of Cleaner Production, 218, 357-366. 
Ockwell, D., Watson, J., Mallett, A., Haum, R., MacKerron, G., \& Verbeken, A.-M. (2010). Enhancing developing country access to eco-innovation: the case of technology transfer and climate change in a post-2012 policy framework.

Oltra, V., Kemp, R., \& De Vries, F. P. (2010). Patents as a measure for eco-innovation. International Journal of Environmental Technology and Management, 13(2), 130-148.

Ottman, J. A., Stafford, E. R., \& Hartman, C. L. (2006). Avoiding green marketing myopia: Ways to improve consumer appeal for environmentally preferable products. Environment: Science and Policy for Sustainable Development, 48(5), 22-36.

Palmer, K., Oates, W. E., \& Portney, P. R. (1995). Tightening environmental standards: the benefit-cost or the no-cost paradigm? Journal of Economic Perspectives, 9(4), 119-132.

Pastakia, A. (1998). Grassroots ecopreneurs: Change agents for a sustainable society. Journal of Organizational Change Management.

Polzin, F., von Flotow, P., \& Klerkx, L. (2016). Addressing barriers to eco-innovation: Exploring the finance mobilisation functions of institutional innovation intermediaries. Technological Forecasting and Social Change, 103, 34-46.

Popadic, M., Pucko, D., \& Cerne, M. (2016). Exploratory innovation, exploitative innovation and innovation performance: The moderating role of alliance partner diversity/raziskovalne inovacije, uporabne inovacije in ucinkovitost inovacij: Vloga moderiranja povezanih raznolikih partnerjev. Economic and Business Review for Central and South-Eastern Europe, 18(3), 293.

Porter, M., \& Van der Linde, C. (1995). Green and competitive: Ending the stalemate. The Dynamics of the Eco-Efficient Economy: Environmental Regulation and Competitive Advantage, 33.

Prud'homme, D. (2017). Utility model patent regime "strength" and technological development: Experiences of China and other East Asian latecomers. China Economic Review, 42, 50-73.

Russo, M. V., \& Fouts, P. A. (1997). A resource-based perspective on corporate environmental performance and profitability. Academy of Management Journal, 40(3), 534-559.

Sáez-Martínez, F. J., Díaz-García, C., \& Gonzalez-Moreno, A. (2016). Firm technological trajectory as a driver of eco-innovation in young small and medium-sized enterprises. Journal of Cleaner Production, 138, 28-37.

Sambasivan, M., Bah, S. M., \& Jo-Ann, H. (2013). Making the case for operating "Green": Impact of environmental proactivity on multiple performance outcomes of Malaysian firms. Journal of Cleaner Production, 42, 69-82.

Schaltegger, S. (2016). A framework and typology of ecopreneurship: Leading bioneers and environmental managers to ecopreneurship. In Making Ecopreneurs (pp. 95-114). Routledge.

Schaltegger, S., \& Wagner, M. (2011). Sustainable entrepreneurship and sustainability innovation: Categories and interactions. Business Strategy and the Environment, 20(4), 222-237.

Shefer, D., \& Frenkel, A. (2005). R\&D, firm size and innovation: an empirical analysis. Technovation, $25(1), 25-32$.

Sørensen, J. B., \& Stuart, T. E. (2000). Aging, obsolescence, and organizational innovation. Administrative Science Quarterly, 45(1), 81-112.

Stucki, T. (2019). Which firms benefit from investments in green energy technologies?-The effect of energy costs. Research Policy, 48(3), 546-555.

Sun, Y., Lu, Y., Wang, T., Ma, H., \& He, G. (2008). Pattern of patent-based environmental technology innovation in China. Technological Forecasting and Social Change, 75(7), 1032-1042.

Suthersanen, U. (2006). Utility models and innovation in developing countries (Vol. 13). Citeseer.

Tang, M., Walsh, G., Lerner, D., Fitza, M. A., \& Li, Q. (2018). Green innovation, managerial concern and firm performance: an empirical study. Business Strategy and the Environment, 27(1), 39-51.

Triguero, A., Moreno-Mondéjar, L., \& Davia, M. A. (2013). Drivers of different types of eco-innovation in European SMEs. Ecological Economics, 92, 25-33.

Weng, H.-H.R., Chen, J.-S., \& Chen, P.-C. (2015). Effects of green innovation on environmental and corporate performance: a stakeholder perspective. Sustainability, 7(5), 4997-5026.

Withers, M. C., Drnevich, P. L., \& Marino, L. (2011). Doing more with less: The disordinal implications of firm age for leveraging capabilities for innovation activity. Journal of Small Business Management, 49(4), 515-536.

Woo, C., Chung, Y., Chun, D., Han, S., \& Lee, D. (2014). Impact of green innovation on labor productivity and its determinants: an analysis of the Korean manufacturing industry. Business Strategy and the Environment, 23(8), 567-576.

Wooldridge, J. M. (2016). Introductory econometrics: a modern approach. Nelson Education. 
Wuyts, S., \& Dutta, S. (2014). Benefiting from alliance portfolio diversity: The role of past internal knowledge creation strategy. Journal of Management, 40(6), 1653-1674.

Zacarías, M. A. V., Aguirre, M. C. D., \& Lagunas, E. A. (2015). Sustainable entrepreneurship in developing countries: Is that even possible? Review of Integrative Business and Economics Research, 4(4), 304.

Zhang, D., Rong, Z., \& Ji, Q. (2019). Green innovation and firm performance: Evidence from listed companies in China. Resources, Conservation and Recycling, 144, 48-55.

Zhen, Y. (2013). China's capital markets. Elsevier.

Publisher's note Springer Nature remains neutral with regard to jurisdictional claims in published maps and institutional affiliations. 